\title{
The Ethics of Aesthetics
}

\author{
KNUT BRYNHILDSVOLL
}

\begin{abstract}
In my article I shall deal with the role of modern literary criticism as exercised by critics working for influential newspapers, journals and public media. I will discuss the evaluating standards and the judgment criteria. I will also examine the independence and moral integrity of critics working in close cooperation with big publishing houses. An important part of my article will focus on the jeopardized balance in book business which threatens to make the critics vulnerable to compromises and loss of ethical credibility. As a consequence of the critic's cooperation with the sales departments of the publishing houses, he might overlook good literature and promote best-sellers, thus giving priority to a category of books which seldom proves to be of lasting value.
\end{abstract}

Keywords: bestseller; commercialism; book-business sales-dominance; ethics; aesthetics; marketing

As early as 1965 Walter Müller-Seidel published a critical study on problems concerning the evaluation of literary texts. He provided his book with the subtitle About the Scientific Use of Non-scientific Topic, claiming that literary critics never succeeded in elaborating suitable standards for literary criticism as a scientific topic. Ever since the beginning of literary evaluation the norms have changed according to the predominant literary taste and the theoretical concepts of creativity. ${ }^{1}$ Various theories have been launched but no single approach has won acceptance as a sustainable guideline for evaluation. The lack of intersubjective constants is easy to explain. The objects of literary evaluation are verbal texts which in the course of time change their receptive appeal in accordance with the changing social and aesthetic requirements. The citizens of ancient Rome used to say: "Tempora mutantur, et nos mutamur in illis." You may easily apply this proverb to literary representations, maintaining that "times are changing,

1 This lack of constancy is responsible for disparate evaluations of the same work through centuries. According to Don Ritter "the judgment of an artwork is dependent on aesthetic features and aesthetic perspective used by a person for judging it. Using this model disagreements on the aesthetic value of a work art are viewed as the consequences of people using different aesthetic perspectives.” (Ritter 2008)

DOI: https://doi.org/10.12697/IL.2017.22.2.2 
and the texts are changing with them." This protean character of literary texts makes it difficult to find appropriate evaluation criteria. Still, we face some of the same problems that were addressed by Müller-Seidel in his monograph: How is it possible to change a non-scientific topic into a scientific one?

As a first step it may be useful to glance at some of the most frequent terms which critics favour when attributing characteristics to literary works. Among the evaluating expressions one finds quality significations which oscillate on a wide scale between good and bad. However, the descriptions 'good' and 'bad' have no use as long as they are based on the object's appeal to the critic's own feelings or tastes. In order for criticism to achieve scientific status, it is necessary to elaborate criteria and judge the respective works in relation to them. Basically, no artistic work has a worth of its own. It gains a scientific quality as far as it is related to a value system. Throughout the ongoing succession of literary periods and paradigmatic shifts the evaluating categories 'good' and 'bad' have remained constant. Because the contradictory designations are rooted in moral philosophy, it is important to make a distinction between the ethical and the aesthetic use of the adjectives. It makes a difference if you say this person or this action is good or if you say this novel or this poem is good. That means a good book is good in a different sense than a good person is. Most frequently the ethical evaluation of literary texts refers to the inherent interplay between figures or actions; the evaluation act concentrates on the moral qualities of the designation 'good'. When a work of art fulfills the theoretical and artistic demands of a certain time, it is a good work, where the predicative good refers to the aesthetic qualities of textual presentation. Both the evaluation of content, figures and form share a common essential feature: good is what exists according to the respective norms of a genre, social context or cultural tradition. However, due to the decline of norms the diversity of literary expressions has increased, the result of which is that the critical profession has lost a stable basis and consequently tends to be arbitrary. Ethical criticism has reached a critical point. As an agent in the market economy, the critic more or less cooperates with the business departments of the publishing houses in pushing the sale. Under such conditions the public attention is drawn away from good literature and turned to best-sellers. The invisible alliance between market-oriented powers has in Norway paved the way for a development which secures the leading publishing houses the biggest share of the sales. The promotion strategy of the publishers suggests that there is a category of books which is superior to the good book. The term 'bestseller' refers to the sales quota, not to the quality of the book.

Below I will examine the unethical practice of the two biggest publishing houses in Norway dominating the market. Through their trade advantages the competitive principles of the market economy are to a large extent set aside. 
One of the reasons for this imbalance is their economic superiority which allows them to produce books which cover the demand for such genres as crime novels, biographies, children's books and of course schoolbooks. The most important advantage however is that the two biggest Norwegian publishing houses own and run about 90 percent of all bookshops in the country. And they exploit this monopoly by making their shops platforms for visualizing their own products. Whereas the books of the two biggest publishing houses occupy most of the space inside the shops and in the window display, the books of the smaller book producers very often are not available or available without being directly visible. This attention-grabbing practice offends against equal marketing conditions and has been criticized as unfair. The big bookshops, mostly located in large department stores, have adapted the display tactics of museums, where the exhibition character of the book arrangements is striking. Numerous copies of the same book are piled up like book towers or pyramids, ignoring the fact that these heavy constructions oppose the spiritual tenderness emerging from the fictional contents inside the book covers. By the way, this vulgar promoting practice forms a significant contrast to comparable book buildings in the country's libraries, where it is usual during Christmas time to build Christmas trees from books and illuminate them with glass candles and bells as a token of books' mental emanations. The trade hegemony shows that there is a need for a controlling authority which, following the German model, observes the business activities in order to prevent any one business becoming a market leader. In the struggle between cultural and business principles it is obvious that moneymaking is dominant. As the German philosopher Peter Sloterdijk has observed, the opposition 'good-bad' has been replaced by 'fresh-perishable', a change which he comments with the words: "Art market and fish market converge" (Sloterdijk 2012: 206) the result of which is that books selling poorly are twice a year sold in plastic bags according to their weight, for instance a five-kilo bag of books. The life-time of average books has been reduced to one year or less; thereafter they are being sold or destroyed. Books have been degraded to goods, worth less than toilette paper that can be stored for a long time. The priority of business interests is a serious attack on the fundamental values of cultural variety and ethical responsibility, moreover a crucial undermining of the publishers' educational and informative commitments.

The bookselling branch in cooperation with literary critics has developed a system of book promotion which ascribes quality to books analogously with school reports or sport events. Inside the bookshops one finds ranking lists from 1 to 20, which change every week according to the bestseller lists in magazines like the German Der Spiegel. The lists mirror the evaluations made by media celebrities, whose tastes and preferences give birth to short selling or long 
selling bestsellers. It is significant for the contemporary marketing strategies that a limited number of star critics have conquered a position which enables them to control the reception and affect the public opinion in an one-sided way. From an ethical point of view the multimedia promotion of selected books through a number of so called specialists imply the risk of prejudiced judgments because it narrows the scope and draws attention to books recommended by the promoting division of publishing houses. A matter of particular interest is the star critic's self-conceit, which threatens to make him a victim of his own vanity. The German critic Marcel Reich-Ranicki won acceptance as the pope among critics, and as such he could, like his Vatican counterpart, claim to be unfailing when judging the quality of literary texts. Pretensions like that are of course meaningless. Nowadays it is more difficult than ever before to express a final judgment for the simple reason that the lack of suitable norms makes it impossible to verify the critic's assertions.

Even though the traditional bookshops have recently lost much of their market share to mail-order firms like Amazon, which deliver books quickly and to a good value with drones directly at the customer's door, the experience nevertheless shows that at least in Norway the biggest bookshops still maintain their monopoly and consolidate their leading position through adaptation to the changing market conditions. Due to the readjustments of the publishing activity and the market structure, the role of the critic as the one who at the same time evaluates works of art and delivers recommendations to the publishing houses and the readers have changed. Star critics have through this double bind exposed themselves to a divided loyalty. They are like characters in Goldoni's Servant of Two Masters. As insiders and outsiders at the same time, they are not free to do their job as a critic with the required neutrality. It is likely that the critic will never disapprove of a manuscript that he himself has recommended for publication. That is why too close cooperation between the different departments in bookbusiness paves the way for a more or less accidental evaluation and a loss of critical integrity. The de-escalation of quality demands makes it easier to be partners in making bestsellers. As far as the critics are concerned the loss of evaluating standards has made them vulnerable to evaluating compromises in the course of which they threaten to make themselves redundant.

Among the management of the big publishing houses good books are appreciated, but the better selling books enjoy an even higher esteem. Thanks to the profit made in bestseller business, the leading book publishers are capable of reinvesting money in books selling not so well and thus fulfil their cultural obligations without loss of prestige. Yet their dominance is so big that the government many years ago had to introduce an arrangement which has attracted much attention. In order to re-establish a certain balance in the 
book publishing business, the ministry of cultural affairs decided to support all publishers with a purchase practice, according to which the ministry buys 1000 copies of every book of fiction in the Norwegian language and distributes a copy to every library in the country.

In the following I want to take a closer look at the economic evaluation of the country's book production and book selling practice with regard to the ethical implications resulting from the commercialization principles. Many publishers are still aware of their special responsibility as administrators of cultural value, but under market conditions it remains difficult to keep the balance between ideal targets and the temptation of earning money. Today it is evident that the big publishing houses are more business-minded than they used to be and are no longer humble guardians of ethical and spiritual values. At the same time the role of literary criticism has changed radically as a result of the suspension of literary standards. The disconnection of literary critic from evaluation criteria facilitates a critical attitude based on the critic's own predilections and subjective prejudices. This is probably unavoidable. According to the new reception theory, good literature differs from the traditional one through its violation of the prevailing rules of artistic writing. Facing a situation where creativity is not the result of sticking to valid parameters but it results from disregarding aesthetic rules, the critics are dependent on new evaluation methods without having any preconceived rules for their critical assessments. This lack of reliable parameters exposes the critics to criticism that their evaluations are worthless and fail to provide insight into the quality of the literary work. It is obvious that literary criticism is undergoing a serious crisis, but at the same time the crisis opens up new ways of developing evaluating methods. In discussions about how to cope with the new situation, an opinion has been voiced that, confronted with the break-down of credible worth-systems, one is in need of a different approach to artistic writing. Since it does not make sense any more to explain the worth of literary texts through statements concerning their compatibility with absolute and timeless aesthetic requirements, many critics argue that the best interpretation is the one which succeeds in developing to the full the semantic potential of literature. Accordingly, the text achieves quality through the reading act. The reader's response decides how good a narrative is.

The recent history of literary criticism shows that there are hierarchies of critical esteem which attribute to literary works value on a scale ranging from 'excellent' via 'good', 'semi-good' to 'bad'. In the German language there is a word which exactly refers to this way of vertical evaluation; it is the word Einstufung, which lets us know at which level a book is settled, if it is, so to say, on the fourth or the ninth 'floor'. This way of evaluation is very smart; it makes use of an architectural metaphor to express the worth of a written text. Such spatial 
classifications might be very useful for publishers in their marketing strategies. By the way, their inventiveness seems to be limitless when attempting to increase the turnover. Recently the bookshops introduced a slogan from the clothes shops that offers customers a choice to "take three, and pay for two!". The book market and the clothes market have converged.

As the present avant-garde literature manifests itself as modernization in progress, the critic is left to his own devices, and if he is a good reader, he becomes a co-producer of the text. The lack of preceding measures necessitates a re-evaluation of the critic's job. Faced with demanding modern texts, he needs to mobilize all his intellectual abilities in order to bring about a good reading, which is a good reading among a lot of other good readings. As there are no prescriptive ways of approaching the complexity of modern narrative, there is no such thing as a final reading, only a good or a bad reading. It is of course a great challenge and a risky business to pronounce judgements on a modern experimental novel. It requires that the critic invests the whole specter of his educational and human experiences in his readings and proves capable of extracting the surplus of his observations and forwarding his conclusions to his readers. However, many critics prefer avoiding critical engagement at a high theoretical level. It is far more pleasant to deliver judgments at a commonsensical level. One can notice the emergence of a new type of star critics with a rather low reading but a high entertaining capacity, who dominate the discussions on TV, in the journals and newspapers and leave their mark on the reading community. Through their omnipresence in public media they obtain a status as masters of quality ranking that provides them with authority, which jeopardizes the cultural variety of opinions and threatens to establish a one-sided picture of the literary market. The star critic remains in spite of his disputed competence a powerful person who through his reputation achieves economic profit for a publishing house simply by declaring a rather mediocre novel a masterpiece. The art market and the trade practice encourage such a practice. "It promotes an elite which has no similarity with an elite." (Rauterberg 2015: 194)

Most studies of literary criticism underline the close connection between ethical and aesthetic components. If ethical criticism wants to cover the entire field of this reciprocity, it is unavoidable to touch on problems concerning the relationship between the author and his writings, particularly when there is a striking dissociation between the aesthetic quality of an author's works and his personal shortcomings as a citizen. Especially in times of ideological and political conflicts there were numerous examples of writers who joined the wrong side and as a result of their mistake were ignored by the reading community, even though among connoisseurs they enjoyed high esteem as masters of artistic writing. 
Strictly speaking the inclusion of biographic documents in literary research is disputed. When literary criticism deals with the ethical dimension of fictional speech it is reasonable to a certain degree to consider the author, who has dispersed (spread over) parts of himself on the fictional figures of his books. Certainly, Ibsen refused to be held responsible for what the figures in his plays say, but he could hardly deny his creative paternity. It is up to literary research to decide if or to which extent the trans-textual world of the author and his lived life is to be included in the ethical evaluation of a text with close links to biographical facts. This is however far too complex a question to be discussed in this context.

At the end of my discussion it may be useful to take a look at a figure whose influence in the fine art scenery is comparable to that of the star critic, namely the collector of paintings. Together with curators and gallerists he is by virtue of his economic and purchasing power a trendsetter, who controls the art market and draws general lines for what is "in" in art business and what is marketable among the variety of art objects. It is significant that "the established network of curators, galleries, and museums that sell and exhibit professional artworks are responsible for determining what is art and what is art not." (Ritter 2008) The big collectors today are big banks, companies, insurance agencies, whose economic superiority mostly is bigger than that of the private and public art museums. Through the purchasing power of a neo-feudal financial nobility the value of art declines to its market value. Art value is no more in the first place a matter of artistic craftsmanship and creativity, but of salability. As far as the criteria of a good painting are not derived from intrinsic features, art is subject to alienation and manipulation. The new relationship between market and aesthetics touches on ethical questions like Why art and for whom? Why follow one's inner voice and inspiration? It proves more lucrative to join the trendsetting practice of curators and collectors, who themselves occasionally serve as employers whose main intention is to use paintings as investment objects. The sponsoring of art through wealthy patrons or institutions "only furthers a nimbus of something extraordinary, elitist and in a consummating sense exclusive. The pleasure of the superficial characterizes the ethics of this aesthetics." (Rauterberg 2015: 116)

Normally questions related to the relationship between ethics and aesthetics evoke great emotions, especially in novels dealing with authentic themes and motifs. The problem of ethical responsibility comes to a head in fictional autobiographies, when the author pretends to give a truthful representation of himself and those closest to him without leaving out any compromising details. In recent years the most controversial fictional autobiography in Norway has been Karl Ove Knausgård's novel My Struggle, which in six volumes tells the story of the author's life from his early childhood up to present times including 
family conflicts and daily banalities, mixing documentary facts with reflections on social, political, psychological and topical questions, culminating with a 400 pages long essay on Adolf Hitler and his opus magnum Mein Kampf serves as title for the six volumes. In Norway Knausgård's novel has reintroduced a documentary form of fictional presentation, which actualizes questions concerning the connection between ethical and aesthetical components in literary texts. The author's use of identifiable living models is a very sensitive practice because it touches on problems regarding the protection of the privacy of the involved individuals. Simon Critchley is however convinced that "interesting art cannot be unethical" and he bases his opinion on the inherent character of art: "I think that interesting art is always ethical. It is organized around ethical demand." (Critchley 2014: 32) He has not defined precisely what the ethical claim comprises, but from his use of the term it can be defined as a general state of mind, within which one finds a plurality of moral decisions, that means "that art can be ethical beyond being moral." (Ibid.29) I would like to add that one should keep in mind that the ethical realization of a work of art implies the quality of the artistic demand as well. It is a well-known fact that what at the level of content in a work of art is terrible and evil, at the level of artistic presentation may be good or excellent as well. The aesthetic representation of the evil may however turn out to be counter-productive if it refrains from revealing the absolutely disastrous behind its surface. It is a matter of finding the appropriate way of giving the evil an ethical foundation, which means a good formal frame, which emphasizes its aesthetical difference and distinguishes it from a plain assertion. Generally speaking good is always good according to a norm. "Who signifies something as art, maintains a normative demand." (Rauterberg 2015: 175) According to Hanno Rauterberg "ethics and aesthetics remain closely connected"; consequently "an artistic position, which defines itself on the basis of ethical intentions, is simply insufficient." (Ibid.)

Many of the questions Walter Müller Seidel raises in his monograph are still waiting for a final solution. Much has been done, not least thanks to the research approaches of professor Nie Zhenzhao, but a lot remains to be done in order to establish ethical literary criticism as a widely accepted scientific discipline, which on the basis of controlled methods is able to guaranty reliable answers to questions regarding the ethical status of artworks. In my paper I have - not surprisingly - drawn the conclusion that the perplexity among occupational critics is spreading along with the breakdown of evaluation standards and the emergence of literary theories, due to which sticking to valid aesthetic norms is a sign of an epigonic way of writing, whereas the permanent transition of conventional writing is the distinguishing mark of creative literature. These new theories, which advocate modernization in progress, leave the critics 
alone with their evaluations. Under such conditions a good critic is the one who is capable of "relating his reviews to the transmitted richness in form and creations." (Rauterberg 2015: 175) The application of complex aesthetic theories to works of art is by contrast not always recommended because there is a clear tendency that the theory is not primarily used to shed light on the literary works, but to demonstrate its own applicability. The question is how meaningful it is to use scientific measures in daily art reviews in newspapers and other media. The research claim should be reserved for those who independent of job considerations can do justice to all aspects of the ethical implementation of aesthetical structures.

\author{
Knut Brynhildsvoll \\ knut.brynhildsvoll@ibsen.uio.no \\ Senter for Ibsen-studier \\ Postboks 1166 Blindern \\ NO - 0316 Oslo \\ NORGE / NORWAY
}

\title{
Bibliography
}

Critchley, S. 2014. Creating Interstices: On Ethics, Politics, and Curatorship. Conversation with Miguel Á. Hernández-Navarro. - N. Mörtmann, A. Krauss, eds., Scandalous. A Reader on Art and Ethics. New York: Sternberg Press, 26-39.

Rauterberg, H. 2015. Die Kunst und das gute Leben. Über die Ethik der Ästhetik. Frankfurt am Main: Suhrkamp.

Ritter, D. 2008. The Ethics of Aesthetics. - R. Adams et al., eds., Transdisciplinary Digital Art, Sound, Vision and the New Screen, vol. 7. Berlin, Hamburg, Heidelberg: Springer, 5-14.

Sloterdijk , P. 2012. Zeiten und Tage. Notizen 2008-2011. Berlin: Suhrkamp Verlag. 